\title{
Modeling and Vibration Control for Belt Driving Mechanism
}

正 浜松 弘(北九州高専) 辻 輝生(九州工大)

\author{
今泉 恵司(九州工大院生)
}

正田中 義人(北九州高専)
正 二見 茂(九州工大) $\begin{array}{ll}\text { Hiroshi HAMAMATSU, } & \text { Kitakyushu National College of Technology, Shii,Kokura-minami-ku,Kitakyushu } \\ \text { Keiji IMAIZUMI, } & \text { Kyushu Institute of Technology } \\ \text { Shigeru FUTAMI, } & \text { Kyushu Institute of Technology } \\ \text { Teruo TSUJI, } & \text { Kyushu Institute of Technology } \\ \text { Yoshito TANAKA } & \text { Kitakyushu National College of Technology }\end{array}$

Keywords : Modeling,Vibration control, Belt driving mechanism, Observer, P-PI control, Mechatronics

\section{1. 緒 論}

ベルト駆動機構は,メカトロニクス機器に広範に用いられ, その目的, 用途に応じて様々な形態をとるとともに要求され る性能も多様化し, 高速高精度化が求められている.しかし， ベルト駆動機構では，リニアモータおよびボールねじ駆動機 構に比べ低剛性であるため,ベルトのたわみによる振動が位 置決め時間に影響を及ぼす。また，プーリでベルトに駆動力 を伝達するためプーリとベルトの噛み合いと離脱による周期 的な伝達変動が生じる問題がある。

本研究では, ベルト駆動機構での振動発生メカニズムを把 握し, 外乱オブザーバを組み込むことで高い振動抑制能力を 付加させることを目的とする。

\section{2. 実 験 装 置}

実験に用いたベルト駆動機構の構造を図 1 に示す。駆動は サーボモータで行い, カップリングを介してプーリを回転さ せべルトを駆動する. ベルトの駆動により，ガイドで支持さ れたテーブルが直線運動する.

$$
\text { 3. 振 動発生メカニズム }
$$

\section{1 駆動実験}

ベルト駆動機構の挙動を把握するため傾き $16(\mathrm{rad} / \mathrm{s})$ の位置の 三角波指令を $0.4(\mathrm{~s})$ 間入力する駆動実験を行う。このとき用い た制御則は，図 2 に示す位置の比例，速度の比例積分(P-PI) 制御である。結果を図 3 に示す。

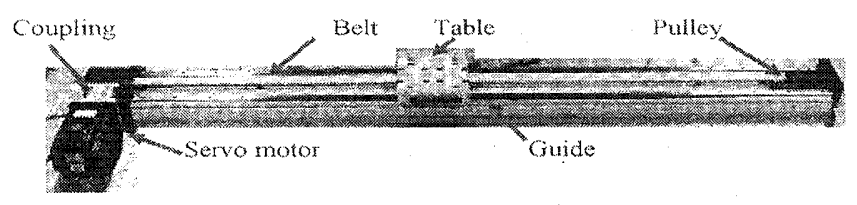

Fig.1 Belt driving table

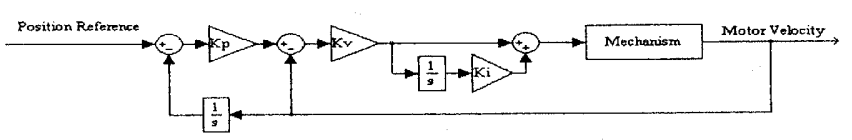

Fig.2 Control system of P-PI

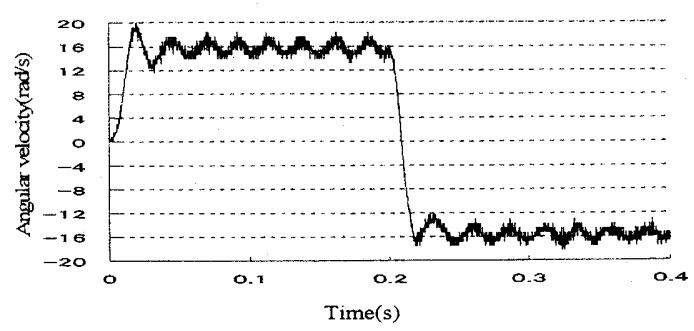

Fig.3 Response of angular velocity
測定結果には， $50 \mathrm{~Hz}$ と $300 \mathrm{~Hz}$ の残留振動が発生している。 の残留振動発生メカニズムとして以下の 2 つを考察する。べ ルトの伸縮による振動, プーリとベルトの㛏み合いによる振 動である。

\section{2 振動発生メカニズム}

3.2 .1 ベルトの伸縮による振動 ベルトは低剛性であるため, 駆動力の伝達の際に振動が発生する.このとき, ベルトの㓮 性はベルト長に依存する. 図 4 にテーブル位置をモータ側, 中央, 反モー夕側と 3 箇所変えたときのトルク指令に対する モー夕角速度の伝達関数を示す. モー夕側を細い実線, 中央 を実線, 反モー夕側を破線で示す．また，このときのトルク に対するテーブル加速度の伝達関数を図 5 に示す. 同様にモ 一夕側を細い実線, 中央を実線, 反モー夕側を破線で示して いる.

図より 1 次の固有振動数が $220 \mathrm{~Hz} \sim 330 \mathrm{~Hz}$ にあり, 2 次の固 有振動数が $480 \mathrm{~Hz} \sim 720 \mathrm{~Hz}$ にある. モータ角速度, テーブル 加速度ともにテーブルの位置を反モータ側に移動させていく につれて矢印で示したように 1 次の固有振動数が $330 \mathrm{~Hz} \sim$ $220 \mathrm{~Hz}$ と低くなっている. また, 2 次の固有振動数では, $480 \mathrm{~Hz}$ $\sim 720 \mathrm{~Hz}$ と高くなっている.これは, ベルト長の増減によっ てベルトの剛性が変化するためである。このことより, 図 3 の残留振動で $300 \mathrm{~Hz}$ 近傍は, ベルトの伸縮により生じている 振動である。

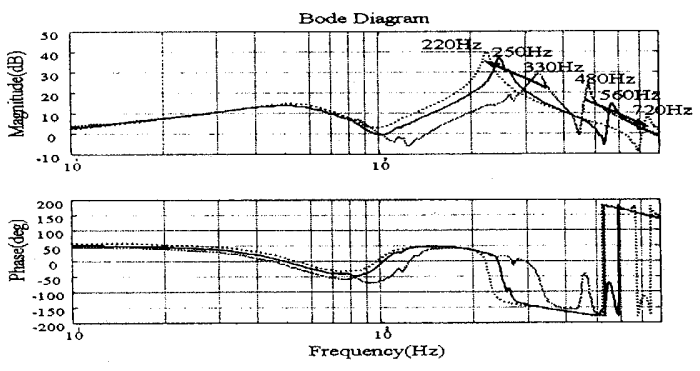

Fig.4 Transfer function of motor
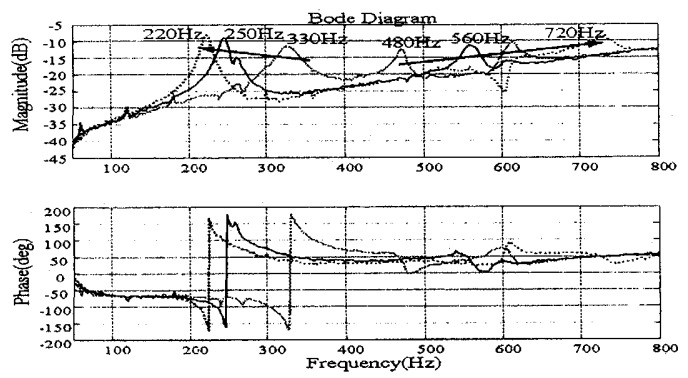

Fig.5 Transfer function of table 
3.2.2 プーリとベルトの噛み合いによる振動：本研究で用い るベルト駆動機構は，プーリとタイミングベルトによりモー タの回転運動を直線運動に変換している. そのため, プーリ とベルトの噛み合いと離脱によって周期的な伝達変動が生じ る.そのため, モータ回転速度に依存した外乱がテーブルと モータに伝達することになる.伝達変動の周期を表すと式(1) になる。

$$
f=\frac{\theta}{2 \cdot \pi \cdot t} \cdot z=\frac{\omega}{2 \cdot \pi} \cdot z
$$

ここで, $\mathrm{f}$ は伝達変動の周波数, $\theta$ はモー夕角度, $\omega$ はモー夕 角速度, $\mathrm{z}$ はプーリ歯数である. 本ベルト駆動機構では, $\mathrm{z}=22$, $\omega=16(\mathrm{rad} / \mathrm{s})$ であるため, $\mathrm{f}=56(\mathrm{~Hz})$ となる. 図 3 の残留振動で $50 \mathrm{~Hz}$ 近傍は, プーリとベルトの噛み合いによる外乱力により 生じている振動である.

\section{1 オブザーバ設計}

\section{4. 外乱オブザーバによる振動抑制}

振幅の大きいプーリとベルトの諊み合いによる振動に着目 し，オブザーバにより，振動抑制を行う。状態変数を観測で きるもの $\mathrm{x}_{1}(\mathrm{t})$ とできないもの $\mathrm{x}_{2}(\mathrm{t})$ に分けてシステムを表すと 以下のようになる.

$$
\begin{aligned}
& {\left[\begin{array}{l}
\dot{x}_{1} \\
\dot{x}_{2}
\end{array}\right]=\left[\begin{array}{ll}
A_{11} & A_{12} \\
A_{21} & A_{22}
\end{array}\right]\left[\begin{array}{l}
x_{1} \\
x_{2}
\end{array}\right]+\left[\begin{array}{l}
B_{1} \\
B_{2}
\end{array}\right] u} \\
& y(t)=\left[\begin{array}{ll}
1 & 0
\end{array}\right]\left[\begin{array}{l}
x_{1} \\
x_{2}
\end{array}\right]
\end{aligned} .
$$

ここで, $\mathrm{x}_{1}$ はモ一夕角速度 $\omega, \mathrm{x}_{2}$ は外乱力 $\mathrm{T}_{\mathrm{L}}, \mathrm{u}$ は入力トル ク $\mathrm{T}_{\mathrm{in}}$ とする. また本研究では, 観測対象を剛体とみなしオブ ザーバを設計するため, $A_{11}=0, A_{12}=-1 / \mathrm{J}, A_{21}=0, A_{22}=0$, $\mathrm{B}_{1}=1 / \mathrm{J}, \mathrm{B}_{2}=0$ とした.

$$
\begin{aligned}
& \dot{x}_{1}=A_{11} x_{1}(t)+A_{12} x_{2}(t)+B_{1} u(t) \\
& \dot{x}_{2}=A_{22} x_{2}(t)+A_{21} x_{1}(t)+B_{2} u(t)
\end{aligned}
$$

となる.また，式(5)より，

$$
\dot{y}(t)-A_{11} y(t)-B_{1} u(t)=A_{12} x_{2}(t)
$$

となる.これらの式を既知の項と末知の項に分け，末知の項 を求めるオブザーバを構成すると式(7)になる.ここで，オブ ザーバゲインを L とし，極配置法で求める.

$$
\begin{aligned}
\dot{\hat{x}}_{2}(t) & =A_{22} x_{2}(t)+A_{21} x_{1}(t)+B_{2} u(t) \\
& +L\left(\dot{y}(t)-A_{11} y(t)-B_{1} u(t)-A_{12} \hat{x}_{2}(t)\right)
\end{aligned}
$$

ここで，中間変数として $\mathrm{x}_{\mathrm{p}}=\mathrm{x}_{2}-\mathrm{Ly}$ を導入にして変形する と以下になる.

$$
\begin{aligned}
& \dot{x}_{p}(t)=\left(A_{22}-L A_{12}\right) \hat{x}_{2}(t)+\left(A_{21}-L A_{11}\right) y(t)+\left(B_{2}-L B\right) u(t) \\
& =\hat{A} x_{p}(t)+\hat{B} y(t)+\hat{J} u(t) \\
& \hat{x}=\left[\begin{array}{ll}
x_{1} & \hat{x}_{2}
\end{array}\right]^{T}=\hat{C} x_{p}+\hat{D} y
\end{aligned}
$$
ただし

$$
\hat{A}=A_{22}-L A_{12} \quad \hat{B}=A_{21}-L A_{11}+\hat{A} L \quad \hat{J}=B_{2}-L B_{1}
$$$$
\hat{C}=\left[\begin{array}{ll}
0 & 1
\end{array}\right]^{T} \hat{D}=\left[\begin{array}{ll}
1 & L
\end{array}\right]^{T}
$$

である．図７にオブザーバの構成図を示す.

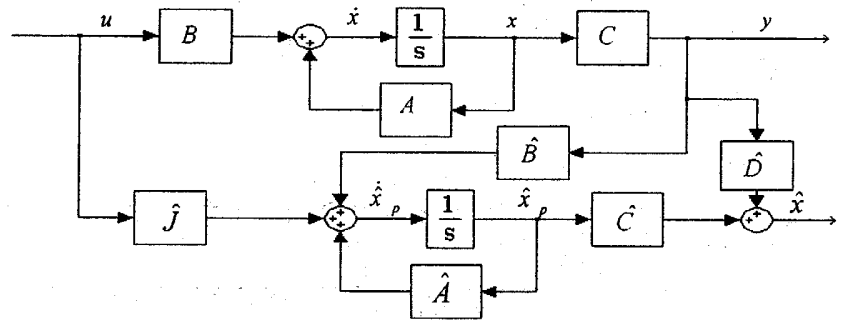

Fig. 7 Block diagram of observer
4.2 シミュレーション

4.2.1 モデル シミュレーションモデルには，図 4 より 1 次の 固有周波数を考慮した二慣性系を用いた．モデルを状態空間 表現で表すと式(11)，(12)となる.

$$
\begin{aligned}
& X(t)=\left[\begin{array}{llll}
x(t) & \theta(t) & \dot{x}(t) & \dot{\theta}(t)
\end{array}\right]^{T}, u(t)=T_{\text {in }}, y(t)=\theta(t) \\
& \ddot{X}(t)=A X(t)+B u(t) \\
& y(t)=C X(t)+D u(t) \\
& A=\left[\begin{array}{cccc}
0 & 0 & 1 & 0 \\
0 & 0 & 0 & 1 \\
-K / M & K \cdot R / M & -C / M & C \cdot R / M \\
K \cdot R / J & -K \cdot R^{2} / J & C \cdot R / J & -C \cdot R^{2} / J
\end{array}\right], B=\left[\begin{array}{c}
0 \\
0 \\
0 \\
1 / J
\end{array}\right], C=\left[\begin{array}{llll}
0 & 0 & 0 & 1
\end{array}\right]
\end{aligned}
$$

ここで, $\mathrm{x}(\mathrm{t})$ はテーブル位置， $\theta(\mathrm{t})$ はモータ角度， $\mathrm{x}(\mathrm{t})$ はテー ブル速度， $\dot{\theta}(\mathrm{t})$ はモータ角速度，K は初期テーブル位置での ベルトの剛性, $\mathrm{R}$ はプーリ半径, $\mathrm{M}$ はテーブル重量, $\mathrm{J}$ はモ 一タの慣性モーメントとカップリングの慣性モーメント，プ 一リの慣性モーメントの和である。

4.2.2 制御系 位置の比例, 速度の比例積分(P-PI)制御に振動 抑制を図るために 4.1 節で作成した外乱オブザーバを組み込 んだ. 制御系のブロック線図を図 8 に示す。ここで， $\mathrm{T}_{\mathrm{L}}$ は外

乱, Tは観測值である.

4.2 .3 速度応答 指令には, 3.1 節で用いた位置の三角波指令 を入力し，外乱 $\mathrm{T}_{\mathrm{L}}$ に $50 \mathrm{~Hz}$ の正弦波を入力した。シミュレー ション結果を図 9, 図 10 に示す，乇ー夕角速度，テーブル速 度ともにオブザーバを組み込むことによって振動を減衰させ ることが分かる。

\section{5. 結 論}

ベルト駆動機構での振動発生メカニズムを把握し, 以下の 結論を得た。

(1) ベルト駆動機構の振動は，プーリとベルトの喵み合いに より発生する外乱により生じる.

（2）外乱オブザーバを設計し，シミュレーションにより振動 抑制効果を確認した。

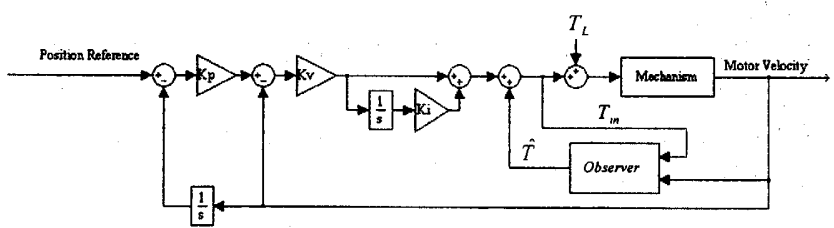

Fig.8 Control system of observer

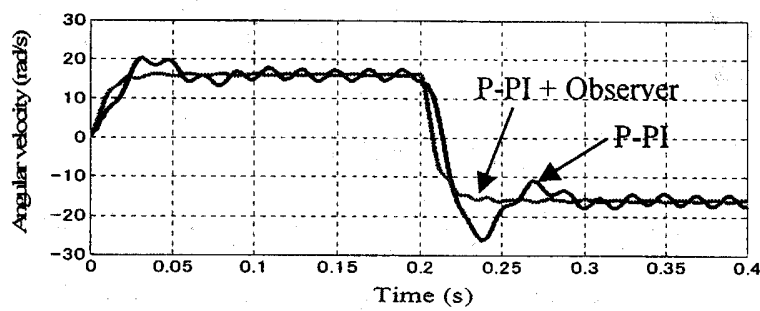

Fig.9 Response of motor angular velocity

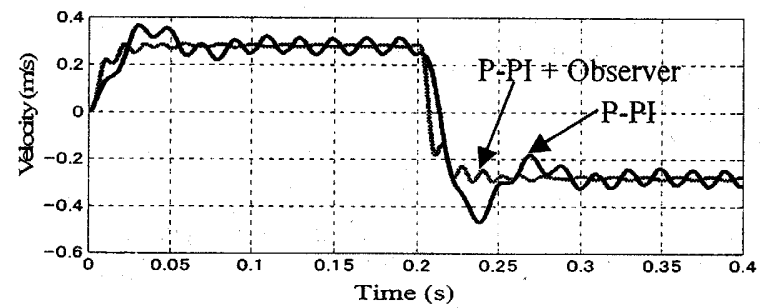

Fig.10 Response of table velocity 